\title{
Major effect genes or loose confederations? The development of insecticide resistance in the malaria vector Anopheles gambiae
}

\author{
Basil D Brooke ${ }^{1,2^{*}}$, Lizette L Koekemoer ${ }^{1,2}$
}

\begin{abstract}
Insecticide use in public health and agriculture presents a dramatic adaptive challenge to target and non-target insect populations. The rapid development of genetically modulated resistance to insecticides is postulated to develop in two distinct ways: By selection for single major effect genes or by selection for loose confederations in which several factors, not normally associated with each other, inadvertently combine their effects to produce resistance phenotypes. Insecticide resistance is a common occurrence and has been intensively studied in the major malaria vector Anopheles gambiae, providing a useful model for examining how insecticide resistance develops and what pleiotropic effects are likely to emerge as a consequence of resistance. As malaria vector control becomes increasingly reliant on successfully managing insecticide resistance, the characterisation of resistance mechanisms and their pleiotropic effects becomes increasingly important.
\end{abstract}

\section{Introduction}

The occurrence of insecticide resistance in insect disease vectors and agricultural pest species poses potential and actual hindrances to successful insect control. Insecticide resistance mechanisms are biological attributes under direct genetic control, and a fundamental issue arising with the development of resistance is the mode and number of genetic factors that translate into resistant phenotypes.

The key caveat imposed on individual insects and on insect populations under insecticide pressure is the production of a resistance phenotype that is sufficient to allow for survival long enough to reproduce. Resistance phenotypes are produced with remarkable regularity in insect populations, and their underlying mutational genotypic changes are tightly conserved, even between species [1].

The imposition of insecticides onto target and nontarget insect populations presents a rapid and dramatic addition to their ecological niche. If they are to survive, their response, drawn from the variation within their

\footnotetext{
* Correspondence: basilb@nicd.ac.za

'Malaria Entomology Research Unit, School of Pathology of the University of the Witwatersrand and the National Health Laboratory Service,

Johannesburg, South Africa

Full list of author information is available at the end of the article
}

genomes, must also be rapid. Two broad scenarios are proposed to explain the rapid evolution of resistance. In one, an insecticide resistance phenotype is likely to be constructed using several unrelated components if sufficiently pressured to evolve within a comparatively small number of generations. This could be necessary under conditions of intense insecticide selection where genes not normally associated with each other at the physiological level are roped together into a loose confederation. Such a confederation then becomes a collection of resistance related genotypic changes, each of independent origin, occurring timeously under conditions of insecticide selection to present as a unified system for the production of resistance. The confederation would be tightly linked under conditions of insecticide selection and could easily disassemble if selection were relaxed. Alternatively, an insecticide resistance phenotype is likely to evolve under intense selection as a single major effect controlled by one or a very small number of mutant alleles or gene duplications. The downstream physiological effect then determines the relative fitness of carrier individuals with or without insecticide selection, ultimately determining the frequency of the resistance phenotype in successive generations.

The development and increasing incidence of insecticide resistance in the major African malaria vector 
Anopheles gambiae Giles has been intensively studied over the past five decades, providing informative data on the development of resistance genotypes and phenotypes.

\section{Anopheles gambiae systematics}

Anopheles gambiae sensu stricto is the nominal member of the An. gambiae species complex. Members within this complex vary widely in their behaviours and malaria vector competence, and they can be identified to species level using species specific markers including isoenzyme alleles, cytogenetic banding sequences and noncoding DNA sequences [2-4]. Anopheles gambiae is widespread across tropical Sub-Saharan Africa [5], and is usually afforded the status of being Africa's most important malaria vector along with An. funestus Giles. However, its status as a single taxon is under revision. Cytogenetic and molecular evidence shows that $A n$. gambiae is genetically structured as a set of discreet breeding units that rarely interbreed. Five chromosomal forms (Bamako, Bissau, Forest, Mopti \& Savanna) and two molecular forms ( $M$ and $S$ ) are recognised [6-8]. The relationship between these two clusters of breeding units is complex and the closest associations between them are found within niche partitioning through divergent adaptation $[9,10]$. It is likely that the $M$ and $S$ molecular forms are distinct species [11-13], and there are distinct differences in the assortment of insecticide resistance genotypes and phenotypes between them.

\section{Detecting and characterising resistance mechanisms}

Insecticide resistance phenotypes are usually assayed using response-to-exposure tests. The most widely used is the standard WHO insecticide susceptibility test for adult anophelines [14]. Using these tests, insecticide resistance phenotypes in An. gambiae M and S forms have been assayed from a wide array of localities across Sub-Saharan Africa. Instances of resistance to organochlorine, pyrethroid (types I and II), carbamate, organophosphate and cyclodiene insecticides have been recorded in $\mathrm{M}$ and $\mathrm{S}$ form populations [15-37].

Descriptions of the underlying resistance mechanisms and the mining of mutant alleles responsible for these physiological adjustments have proved more problematic. Several methods have been employed, in most cases led by response-to-exposure assays. Sequencing of known insecticide target site loci has identified point mutations associated with resistance [38-40]. These mutations induce amino acid substitutions leading to alterations in the structural and chemical attributes of target proteins, rendering them less susceptible to insecticide binding. Such changes in insecticide affinity can be assayed biochemically $[41,42]$, and biochemical techniques also allow for the quantification of detoxification enzyme activities in association with insecticide resistance $[43,44]$. These assays are most informative when backed by quantification of the effects of specific insecticide synergists on resistance phenotype expression. Degenerate oligonucleotides designed from the genome sequences of other insect species have been used to isolate potential detoxification genes in $A n$. gambiae, and subsequent RNA transcription assays have been used to quantify gene expressions in association with resistance [45]. Facilitated by the sequencing of the An. gambiae genome [46], gene regulation and expression of those genes associated with insecticide resistance can now be quantified by microarray and subsequent quantitative polymerase chain reaction assay (qPCR), and specialised microarrays are commercially available $[27,47,48]$. Lastly, genetic linkage disequilibrium analysis and the physical mapping of insecticide resistance quantitative trait loci using proximity to microsatellite markers and single nucleotide polymorphisms (SNP's) has proved extremely useful [40,49-51]. These two approaches are particularly robust because, unlike most other methods, they make no prior assumptions about the resistance mechanisms involved.

\section{Pyrethroid and DDT resistance}

The mechanism most commonly associated with resistance to DDT and pyrethroids in An. gambiae is a reduced target site sensitivity termed knock down resistance $(k d r)$. Two $k d r$ mutations at position 1014 of the S6 transmembrane segment of the sodium channel gene have been identified. The L1014F mutation induces a leucine to phenylalanine substitution whilst the L1014 S mutation induces a substitution of the same leucine with serine $[38,39]$. In both cases, polymerase chain reaction (PCR) diagnostic assays have been developed allowing for the genotyping of individual mosquitoes at this locus, and the co-occurrence of both mutations in single populations has been documented [52]. However, questions over the reliability of inferring resistance phenotype based solely on the diagnosis of $k d r$ genotype have been raised, because correlations between phenotype and $k d r$ genotype are obscure in some instances. Recent data suggest that the correlation between response-to-insecticide phenotype and $k d r$ genotype in An. gambiae is strongest in association with DDT, weaker in association with permethrin (type I pyrethoid) and weakest in association with deltamethrin (type II pyrethroid) $[31,36,53,54]$. Correlations deviating significantly from absolute imply the presence of resistance factors other than $k d r$ [36,54-56] and these likely involve metabolic detoxification as has been demonstrated in An. gambiae populations from Kenya [50], Nigeria, Benin [27,48], Uganda [36] and Ghana [57,58]. 
Metabolic detoxification is the most common mode of insecticide resistance in insects [59]. In order for detoxifying enzyme systems to produce effective resistant phenotypes, transcription and enzyme production must be sufficient to catalyze the metabolism of insecticide at a rate that prevents significant interaction between the insecticide and its neuronal target. Metabolically mediated pyrethroid resistance in An. gambiae is most commonly based on P450 monooxygenase detoxification, with esterases implicated in a few cases. Although both of these enzyme classes are large, resistance tends to emerge in association with the upregulated activities of one or a very small number of genes $[45,48,58]$. There are also instances where $k d r$ is not implicated in DDT resistance in An. gambiae. In these cases the upregulated expressions of specific glutathione-S transferases (GST's) are responsible for the metabolic conversion of DDT $[60,61]$, although single P450 genes have also been shown to metabolise DDT $[62,63]$. Nevertheless, $k d r$ is widespread in An. gambiae [64] and there is a strong trend toward increasing $k d r$ frequencies in An. gambiae populations owing to insecticide selection pressure [65]. Further, $k d r$ haplotypes have arisen independently at least four times in An. gambiae [66] and it is highly likely that the presence of $k d r$ in the $\mathrm{M}$ form was transferred through introgression from the $S$ form [67]. These data show that the $k d r$ locus presents as a strong candidate for selection in the presence of DDT and type I pyrethroids.

In summary, DDT resistance in An. gambiae is usually conferred either by $k d r$ or by GST mediated detoxification, aligning best with the development of single major effect genes. On the other hand, pyrethroid resistance is most likely to emerge as a combination of $k d r$ and metabolic detoxification, aligning best with the concurrent development of several resistance factors. Microarray analysis of a Nigerian $A n$. gambiae population provides a useful example of a resistance confederation, where differential gene expression identifies several resistance associated factors including detoxification genes and cuticle deposition genes. These present in this population in conjunction with $k d r$, leading to significant pyrethroid resistance [27].

\section{Carbamate and organophosphate resistance}

Carbamates and organophosphates share acetylcholinesterase as their target site, and at least two functional mutations in acetylcholinesterase 1 (ace-1) have been identified in insect species that offer reduced target sensitivity to intoxication [68]. One of these, ace-1R (G119S), is most commonly associated with resistance to these insecticides in An. gambiae [30,69,70]. This mutation is found in association with resistance in the $\mathrm{M}$ and $\mathrm{S}$ molecular forms [34], and sequence comparison between forms at this locus suggests a unique mutational event that co-occurs in both forms through introgression from the $\mathrm{S}$ form [71].

Esterase mediated sequestration of carbamates and organophosphates is documented for a number of insect species [72-74] and there is some evidence of this mode of resistance to the carbamate bendiocarb in An. gambiae $\mathrm{S}$ form from the Democratic Republic of Congo (unpublished data). This mode of resistance also develops as a single major effect that tends not to appear in conjunction with acetylcholinesterase target site mutations.

\section{Cyclodiene and phenyl pyrazole resistance}

Cyclodienes and the phenyl pyrazole insecticide fipronil are antagonists of the GABA-gated chloride channel. Dieldrin resistance was first described in An. gambiae in Nigeria [75]. It was shown to be inherited in a simple Mendelian fashion with evidence of two resistance alleles for the same locus, one dominant and the other codominant [76-78]. Resistance to dieldrin $(r d l)$ is widespread in $A n$. gambiae, particularly in the West African region [79], and has been associated with mutations occurring in the M2 transmembrane domain of the $\gamma$ amino-butyric acid (GABA) receptor in various insect species [80]. Cross resistance between dieldrin and fipronil has been recorded in the two An. gambiae laboratory strains IAN P20 and CIG [81] and a mutation conferring the substitution alanine 296 to glycine is associated with dieldrin resistance in these strains [40]. Evidence of a P450 mediated metabolic component, in addition to $r d l$, has been suggested for an $A n$. gambiae $\mathrm{S}$ form population in Ghana [79].

\section{Pleiotropy}

Pleiotropy is used here in the classical sense as the effect of a single gene/factor on multiple traits. Pleiotropy is a direct consequence of reduced target site sensitivity mutations $(k d r$, Ace-1R and $r d l)$, which not only confer reduced sensitivity to insecticide but also allow for continued ion flow regulation and enzyme function. This dual functionality also accounts for the highly conserved nature of these mutations across insect species.

The most important pleiotropic effect of insecticide resistance is reduced fitness [82]. Fitness costs are usually measured in terms of adaptive and reproductive characteristics as well as comparative measurements of resistance gene frequencies prior to and following insecticide selection. It is likely that $k d r$ in $A n$. gambiae carries reduced fitness in the absence of insecticide [65], although super- $k d r$ in house flies appears stable [83], as does $k d r$ in the peach-potato aphid [84]. There is however evidence of selection against $k d r$ homozygotes in peach potato aphids in the absence of insecticide [85]. 
Anopheles gambiae individuals homozygous for ace-1R are likely to show enhanced fitness only in the presence of insecticide [86], because their pupal mortality is high and their body weight compromised in comparison to wild-type homozygous individuals [70]. Dieldrin resistance in association with $r d l$ mutations reduces fitness in the absence of cyclodienes in An. gambiae and $A n$. stephensi $[87,88]$ and, to a lesser extent, in Drosophila [1]. In An. gambiae, homozygous resistant (RR) samples showed reduced fecundity in females and reduced mating competitiveness and stimulus flight response in males compared to the other genotypes $[87,88]$.

DDT resistance by GST mediated metabolism does not incur a fitness cost in An. sacharovi [89], and this is likely the case for $A n$. gambiae as well [90]. Similarly, P450 mediated pyrethroid resistance does not incur a fitness cost in An. funestus [91]. A common observation in these cases is the persistence of resistance phenotypes, in wild populations and laboratory colonies, in the absence of insecticide selection. However, a P450 pyrethroid resistance genotype associates with reduced fitness in Culex pipiens quinquefasciatus [92].

The effect of pleiotropy is also important at the chromosomal level. For example, dieldrin resistance in An. gambiae has been chromosomally mapped to division $23 \mathrm{C}$ on chromosome arm 2L $[46,93,94]$. This position falls within the breakpoints of paracentric inversion $2 \mathrm{La}$, which is an extremely common inversion polymorphism in $A n$. gambiae. Inversion $2 \mathrm{La}$ is highly stable as a polymorphism in the An. gambiae IAN P20 and CIG laboratory colonies [81], because both show positive heterosis whereby $2 \mathrm{La}+2 \mathrm{La}$ heterozygotes are typically found in excess when compared to that expected under Hardy-Weinberg assortment. Further, dieldrin resistant and susceptible females, characterised as such by their responses to dieldrin exposure, show a close association between the "standard" arrangement $2 \mathrm{La}+$ and the resistance phenotype. Individuals carrying the $2 \mathrm{La}+/ 2 \mathrm{La}+$ and $2 \mathrm{La}+/ 2 \mathrm{La}$ arrangements were able to survive exposure to dieldrin whilst those with the alternative $2 \mathrm{La} \backslash 2 \mathrm{La}$ arrangement could not, with only a few exceptions in CIG [81]. These data suggest that dieldrin resistance in these two colonies is continually maintained at a high level (phenotypic frequency of approximately 75\%) by the continual maintenance of inversion $2 \mathrm{La}$ as a polymorphism [90]. Despite the effects of a fitness cost associated with dieldrin resistance in An. gambiae $[87,88]$, cross-over suppression associated with inversion polymorphism coupled with the positive heterotic effect of $2 \mathrm{La}$ in these colonies ensures the continual inheritance of the dieldrin resistance allele through successive generations without insecticide selection. Generally, inversion heterokaryotypes carry a fitness advantage through multiple heterozygosity at loci within the breakpoints [95], and this enhanced fitness is inadvertently conferred on the dieldrin locus by linkage disequilibrium. Inversion $2 \mathrm{La}$ is also associated with larval habitat [96], adaptation to aridity [97,98], resistance to desiccation [99] and Plasmodium infectivity [100]. These traits affect the assortment and frequencies of $2 \mathrm{La}$ genotypes, and are likely to exert a strong influence on the frequency of dieldrin resistance where it occurs in An. gambiae.

The development of multiple resistance mechanisms conferring resistance to multiple insecticides in single populations has been recorded in $A n$. gambiae $[19,21,101]$. These scenarios are likely to have developed as a result of prolonged insecticide selection, and linkage disequilibria between their controlling loci may influence the spectrum and frequencies of within population resistance phenotypes over time, depending on the conditions of selection.

Under prolonged insecticide selection, the relative dominance or recessivity of resistance alleles defines the rate at which they are likely to approach fixation. Most reduced target site sensitivity mutations are recessive, and recessive alleles only present for selection when homozygous. As such the selection for resistance under conditions of recessivity is initially slow because most resistance allele carriers are heterozygous at affected loci. However, the complete exclusion of wild-type alleles under conditions of resistance recessivity enables a rapid subsequent increase in resistance allele frequency toward fixation. Resistance allele dominance can also lead to fixation under selection but the process tends to be prolonged because wild-type alleles survive selection in heterozygous carriers. Those factors controlling enzyme-mediated detoxification are likely to be dominant or co-dominant in expression. Whether by dominance or recessivity, resistance allele fixation can occur if insecticide selection is sufficiently intense and prolonged, and fixation at resistance loci will ultimately negate the deleterious fitness effects of resistance alleles.

The reduced fitness effects of deleterious resistance alleles can also be compensated under conditions of prolonged selection without the need for fixation. Prolonged selection allows for the development of small effect compensatory mutations whose additive phenotypic effects negate the reduced fitness associated with the major effect gene [102].

\section{Conclusion}

Insecticide resistance mechanisms and their controlling genetic factors are generally highly conserved in insects. Despite this, the incidence of insecticide resistance is increasing in malaria vector species. In $A n$. gambiae, 
insecticide resistance phenotypes usually develop under the control of single major genetic factors. Those factors involving mutations in target site loci are likelier to reduce fitness and are only advantageous to carriers in the presence of insecticide. Selection generally acts against these alleles and they tend to drift out of populations in the absence of insecticide. However, a combination of factors producing a single resistance phenotype also occurs in some instances. These factors invariably involve metabolic detoxification, are less likely to reduce reproductive and physiological fitness in carriers, and tend to be stable over time, even in the absence of insecticide selection. Resistance allele fixation, compensatory mutations and linkage disequilibrium - particularly that associated with polymorphic chromosomal inversions - can lend stability to otherwise deleterious resistance alleles, facilitating their continual inheritance through generations regardless of the presence or absence of selection.

Malaria vector control is becoming increasingly reliant on successfully managing insecticide resistance, which forms a crucial part of broader integrated vector management (IVM) [103]. Therefore, the characterisation of resistance mechanisms and their pleiotropic effects is important, as this information offers directives for each target vector population by identifying which control strategies are likely to prove most effective against them.

\section{Acknowledgements}

Special thanks to the anonymous reviewers of this manuscript for their invaluable input and advice.

\section{Author details \\ ${ }^{1}$ Malaria Entomology Research Unit, School of Pathology of the University of the Witwatersrand and the National Health Laboratory Service, \\ Johannesburg, South Africa. ${ }^{2}$ Vector Control Reference Unit, National Institute for Communicable Diseases, NHLS, Private Bag X4, Sandringham, 2131, South Africa.}

\section{Authors' contributions}

BDB drafted the manuscript, LLK edited and contributed to certain sections. All authors read and approved the final manuscript.

\section{Competing interests}

The authors declare that they have no competing interests.

Received: 14 July 2010 Accepted: 17 August 2010

Published: 17 August 2010

\section{References}

1. French-Constant RH, Daborn PJ, Le Goff G: The genetics and genomics of insecticide resistance. Trends Genet 2004, 20:163-170.

2. Green CA: Cytological maps for the practical identification of females of three freshwater species of the Anopheles gambiae complex. Ann Trop Med Parasitol 1972, 66:143-147.

3. Hunt RH: Cytological studies on a new member of the Anopheles gambiae complex. Trans R Soc Trop Med and Hyg 1972, 66:532.

4. Scott JA, Brogdon WG, Collins FH: Identification of single specimens of the Anopheles gambiae complex by the polymerase chain reaction. Am J Trop Med d Hyg 1993, 49:520-529.
5. Coetzee M, Craig M, Le Seur D: Distribution of African malaria mosquitoes belonging to the Anopheles gambiae complex. Parasitol Today 2000, 16:74-77.

6. Coluzzi M, Petrarca V, Di Deco MA: Chromosomal inversion intergradation and incipient speciation in Anopheles gambiae. Boletino Zoologica 1985, 52:45-63.

7. Favia G, Della Torre A, Bagayoko M, Lanfrancotti A, Sagnon NF, Toure YT, Coluzzi M: Molecular identification of sympatric chromosomal forms of Anopheles gambiae and further evidence of their reproductive isolation. Insect Mol Biol 1997, 6:377-383.

8. della Torre A, Fanello C, Akogbeto M, Dossou-yovo J, Favia G, Petrarca V, Coluzzi M: Molecular evidence of incipient speciation within Anopheles gambiae s.s. in West Africa. Insect Mol Biol 2001, 10:9-18.

9. Costantini C, Ayala D, Guelbeogo WM, Pombi M, Some CY, Bassole IHN, Ose K, Fotsing J, Sagnon N, Fontenille D, Besansky NJ, Simard F: Living at the edge: biogeographic patterns of habitat segregation conform to speciation by niche expansion in Anopheles gambiae. BMC Ecol 2009, 9:16.

10. Simard F, Ayala D, Kamdem GC, Pombi M, Etouna J, Ose K, Fotsing J-M, Fontenille D, Besansky NJ, Costantini C: Ecological niche partitioning between the $\mathrm{M}$ and $\mathrm{S}$ molecular forms of Anopheles gambiae in Cameroon: the ecological side of speciation. BMC Ecol 2009, 9:17.

11. della Torre A, Costantini C, Besansky NJ, Caccone A, Petrarca V, Powell JR, Coluzzi M: Speciation within Anopheles gambiae - the glass is half full. Science 2002, 298:115-117.

12. Stump AD, Fitzpatrick MC, Lobo NF, Traoré S, Sagnon NF, Costantini C, Collins FH, Besansky NJ: Centromere-proximal differentiation and speciation in Anopheles gambiae. Proc Natl Acad Sci USA 2005, 102:15930-15935.

13. Lehmann T, Diabate A: The molecular forms of Anopheles gambiae: A phenotypic perspective. Infect Genet Evol 2008, 8:737-746.

14. World Health Organisation: Test procedures for insecticide resistance monitoring in malaria vectors, bio-efficacy and persistence of insecticides on treated surfaces. Document WHO/CDS/CPC/MAL/98.12 Geneva, Switzerland 1998 [http://whqlibdoc.who.int/hq/1998/ WHO CDS CPC MAL 98.12.pdf].

15. Chandre F, Darrier F, Manga L, Akogbeto M, Faye O, Mouchet J, Guillet P: Status of pyrethroid resistance in Anopheles gambiae sensu lato. Bulletin World Health Organisation 1999, 77:230-234.

16. Coetzee M, Horne DWK, Brooke BD, Hunt RH: DDT, dieldrin and pyrethroid resistance in African malaria vector mosquitoes: an historical review and implications for future malaria control in southern Africa. S Afr J Sci 1999, 95:215-218.

17. Etang J, Manga L, Chandre F, Guillet P, Fondjo E, Mimpfoundi R, Toto JC, Fontenille D: Insecticide susceptibility status of Anopheles gambiae s.I. (Diptera: Culicidae) in the Republic of Cameroon. J Med Entomol 2003, 40:491-497.

18. Casimiro S, Coleman M, Hemingway J, Sharp B: Insecticide resistance in Anopheles arabiensis and Anopheles gambiae from Mozambique. J Med Entomol 2006, 43:276-282.

19. Coetzee $M$, van Wyk P, Booman M, Koekemoer LL, Hunt RH: Insecticide resistance in malaria vector mosquitoes in a gold mining town in Ghana and implications for malaria control. Bull Soc Pathol Exot 2006, 99:400-403.

20. Tia E, Akogbeto M, Koffi A, Toure M, Adja AM, Moussa K, Yao T, Carnevale P, Chandre F: Pyrethroid and DDT resistance of Anopheles gambiae s.s. (Diptera: Culicidae) in five agricultural ecosystems from Côte-d'Ivoire. Bull Soc Pathol Exot 2006, 99:278-282.

21. Corbel V, N'Guessan R, Brengues C, Chandre F, Djogbenou L, Martin T, Akogbeto M, Hougard JM, Rowland M: Multiple insecticide resistance mechanisms in Anopheles gambiae and Culex quinquefasciatus from Benin, West Africa. Acta Trop 2007, 101:207-216.

22. Sharp BL, Riedl FC, Govender D, Kuklinski J, Kleinschmidt I: Malaria vector control by indoor residual insecticide spraying on the tropical island of Bioko, Equatorial Guinea. Malar J 2007, 6:52.

23. Adasi K, Hemingway J: Susceptibility to three pyrethroids and detection of knockdown resistance mutation in Ghanaian Anopheles gambiae sensu stricto. J Vector Ecol 2008, 33:255-262.

24. Chouaibou M, Etang J, Brevault T, Nwane P, Hinzoumbe CK, Mimpfoundi R, Simard F: Dynamics of insecticide resistance in the malaria vector Anopheles gambiae s.l. from an area of extensive cotton cultivation in Northern Cameroon. Trop Med Int Health 2008, 13:476-486. 
25. Kamau L, Agai D, Matoke D, Wachira L, Gikandi G, Vulule JM: Status of insecticide susceptibility in Anopheles gambiae sensu lato and Anopheles funestus mosquitoes from western Kenya. J Insecticide Sci 2008, 8:11.

26. Okoye PN, Brooke BD, Koekemoer LL, Hunt RH, Coetzee M: Characterisation of DDT, pyrethroid and carbamate resistance in Anopheles funestus from Obuasi, Ghana. Trans R Soc Trop Med Hyg 2008, 102:591-598.

27. Awolola TS, Oduola OA, Strode C, Koekemoer LL, Brooke BD, Ranson H: Evidence of multiple pyrethroid resistance mechanisms in the malaria vector Anopheles gambiae sensu stricto from Nigeria. Trans $R$ Soc Trop Med Hyg 2009, 103:1139-1145.

28. Betson M, Jawara M, Awolola S: Status of insecticide susceptibility in Anopheles gambiae s.l. from malaria surveillance sites in The Gambia. Malar J 2009, 8:187.

29. Dabire KR, Diabate A, Namountougou M, Toe KH, Ouari A, Kengne P, Bass C, Baldet T: Distribution of pyrethroid and DDT resistance and the L1014F kdr mutation in Anopheles gambiae s.l. from Burkina Faso (West Africa). Trans R Soc Trop Med Hyg 2009, 103:1113-1120.

30. Dabire KR, Diabate A, Namontougou M, Djogbenou L, Kengne P, Simard F, Bass C, Baldet T: Distribution of insensitive acetylcholinesterase (ace-1R) in Anopheles gambiae s.l. populations from Burkina Faso (West Africa). Trop Med Int Health 2009, 14:396-403.

31. Ramphul U, Boase T, Bass C, Okedi LM, Donnelly MJ, Muller P: Insecticide resistance and its association with target-site mutations in natural populations of Anopheles gambiae from eastern Uganda. Trans $R$ Soc Trop Med Hyg 2009, 103:1121-1126.

32. Ranson H, Abdalla H, Badolo A, Guelbeogo WM, Kerah-Hinzoumbe C, Yangalbe-Kalnone E, Sagnon N, Simard F, Coetzee M: Insecticide resistance in Anopheles gambiae: data from the first year of a multi-country study highlight the extent of the problem. Malar J 2009, 8:299.

33. Vezenegho S, Brooke BD, Hunt RH, Coetzee M, Koekemoer LL: Malaria vector mosquito composition and insecticide susceptibility status in Guinea Conakry, West Africa. Med Vet Entomol 2009, 23:326-334.

34. Ahoua Alou LP, Koffi AA, Adja MA, Tia E, Kouassis PK, Kone M, Chandre F: Distribution of ace-1R and resistance to carbamates and organophosphates in Anopheles gambiae s.s. populations from Cote d'Ivoire. Malar J 2010, 9:167.

35. Carnevale P, Toto JC, Guibert P, Keita M, Manguin S: Entomological survey and report of a knockdown resistance mutation in the malaria vector Anopheles gambiae from the Republic of Guinea. Trans $R$ Soc Trop Med Hyg 2010, 104:484-489.

36. Verhaegen K, Van Bortel W, Roelants P, Okello PE, Talisuna A, Coosemans M Spatio-temporal patterns in kdr frequency in permethrin and DDT resistant Anopheles gambiae s.s. from Uganda. Am J Trop Med Hyg 2010, 82:566-573.

37. Yadouleton AW, Padanou G, Asidi A, Moiroux N, Bio-Bangana S, Corbel V, N'Guessan R, Gbenou D, Yacoubou I, Gazard K, Akogbetou M: Insecticide resistance status in Anopheles gambiae in southern Benin. Malar J 2010, 9:83.

38. Martinez-Torres D, Chandre F, Williamson MS, Darriet F, Berger JB, Devonshire AL, Guillet P, Pasteur N, Pauron D: Molecular characterization of pyrethroid knockdown resistance $(\mathrm{kdr})$ in the major malaria vector Anopheles gambiae s.s. Insect Mol Biol 1998, 7:179-184.

39. Ranson $H$, Jenson B, Vulule JM, Wang X, Hemingway J, Collins FH: Identification of a point mutation in the voltage-gated sodium channel gene of Kenyan Anopheles gambiae associated with resistance to DDT and pyrethroids. Insect Mol Biol 2000, 9:491-497.

40. Du W, Awolola TS, Howell P, Koekemoer LL, Brooke BD, Benedict MQ, Coetzee M, Zheng L: Independent mutations in the Rdl locus confer dieldrin resistance to Anopheles gambiae and Anopheles arabiensis. Insect Mol Biol 2005, 14:179-183.

41. Hemingway J, Smith C, Jayawardena KGl, Herath PRJ: Field and laboratory detection of the altered acetylcholinesterase genes which confer organophosphate and carbamate resistance in mosquitoes (Diptera: Culicidae). Bull Entomol Res 1986, 76:559-565.

42. Brogdon WG: Microassay of acetylcholinesterase activity in small portions of single mosquito homogenates. Comp Biochem Physiol 1988, 90:145-150.
43. Hemingway J: A note on simple biochemical methods for resistance detection and their field application in Sri Lanka. Pestic Sci 1989, 27:281-285.

44. Penilla RP, Rodriguez AD, Hemingway J, Torres JL, Arrendo-Jimenez ال I, Rodriguez $\mathrm{MH}$ : Resistance management strategies in malaria vector mosquito control. Baseline data for a large scale field trial against Anopheles albimanus in Mexico. Med Vet Entomol 1998, 12:217-233.

45. Nikou D, Ranson H, Hemingway J: An adult-specific CYP6 P450 gene is overexpressed in a pyrethroid-resistant strain of the malaria vector, Anopheles gambiae. Gene 2003, 318:91-102.

46. Holt RA, Subramanian GM, Halpern A, Sutton GG, Charlab R, Nusskern DR, Wincker P, Clark AG, Ribeiro JM, Wides R, Salzberg SL, Loftus B, Yandell M, Majoros WH, Rusch DB, Lai Z, Kraft CL, Abril JF, Anthouard V, Arensburger P, Atkinson PW, Baden H, de Berardinis V, Baldwin D, Benes V, Biedler J, Blass C, Bolanos R, Boscus D, Barnstead $M$, et al: The genome sequence of the malaria mosquito Anopheles gambiae. Science 2002, 298:129-149.

47. David JP, Strode C, Vontas J, Nikou D, Vaughan A, Pignalelli PM, Louis C, Hemingway J, Ranson H: The Anopheles gambiae detoxification chip: a highly specific microarray to study metabolic based insecticide resistance in malaria vectors. Proc Natl Acad Sci USA 2005, 102:4080-4084.

48. Djouaka RF, Bakare AA, Coulibaly ON, Akogbeto MC, Ranson H, Hemingway J, Strode C: Expression of the cytochrome P450 s, CYP6P3 and CYP6M2 are significantly elevated in multiple pyrethroid resistant populations of Anopheles gambiae s.s. from Southern Benin and Nigeria. BMC Genomics 2008, 9:538.

49. Ranson H, Jensen B, Wang X, Prapanthadara L, Hemingway J, Collins FH: Genetic mapping of two loci affecting DDT resistance in the malaria vector Anopheles gambiae. Insect Mol Biol 2000, 9:499-507.

50. Ranson H, Paton MG, Jensen B, McCarroll L, Vaughan A, Hogan JR, Hemingway J, Collins F: Genetic mapping of genes conferring permethrin resistance in the malaria vector, Anopheles gambiae. Insect Mol Biol 2004, 13:379-386.

51. Black IV WC, Gorrochetegui-Escalante N, Randle NP, Donnelly MJ: The Yin and Yang of linkage disequilibrium: mapping of genes and nucleotides conferring insecticide resistance in insect disease vectors. Adv Exp Med Biol 2008, 627:71-83.

52. Pinto J, Lynd A, Elissa N, Donnelly MJ, Costa C, Gentile G, Caccone A, do Rosario VE: Co-occurrence of East and West African kdr mutations suggests high levels of resistance to pyrethroid insecticides in Anopheles gambiae from Libreville, Gabon. Med Vet Entomol 2006, 20:27-32.

53. Reimer L, Fondjo E, Patchoke S, Diallo B, Ng A, Ndjemai HM, Atangana J, Traore SF, Lanzaro G, Cornel AJ: Relationship between $k d r$ mutation and resistance to pyrethroid and DDT insecticides in natural populations of Anopheles gambiae. J Med Entomol 2008, 45:260-266.

54. Nwane P, Etang J, Chouaibou M, Toto JC, Kerah-Hinzoumbe C, Mimpfoundi R, Awono-Ambene HP, Simard F: Trends in DDT and pyrethroid resistance in Anopheles gambiae s.s. populations from urban and agro-industrial settings in southern Cameroon. BMC Infect Dis 2009, 9:163.

55. Brooke BD: $k d r$ : Can a single mutation produce an entire insecticide resistance phenotype? Trans $R$ Soc Trop Med Hyg 2008, 102:524-525.

56. Protopopoff N, Verhaeghen K, Van Bortel W, Roelants P, Marcotty T, Baza D, D'Alessandro U, Coosemans M: A significant increase in $k d r$ in Anopheles gambiae is associated with an intensive vector control intervention in Burundi highlands. Trop Med Int Health 2008, 13:1479-1487.

57. Muller P, Donnelly MJ, Ranson H: Transcription profiling of a recently colonised pyrethroid resistant Anopheles gambiae strain from Ghana. BMC Genomics 2007, 8:36.

58. Muller P, Warr E, Stevenson BJ, Pignatelli PM, Morgan JC, Steven A, Yawson AE, Mitchell SN, Ranson H, Hemingway J, Paine M, Donnelly MJ: Field-caught permethrin-resistant Anopheles gambiae overexpress CYP6P3, a P450 that metabolises pyrethroids. PLoS Genet 2008, 4: e1000286.

59. Hemingway J, Ranson $\mathrm{H}$ : Insecticide resistance in insect vectors of human disease. Annu Rev Entomol 2000, 45:371-391.

60. Ranson H, Cornel AJ, Fournier D, Vaughan A, Collins FH, Hemingway J: Cloning and localization of a glutathione S-transferase class 1 gene from Anopheles gambiae. J Biol Chem 1997, 272:5464-5468. 
61. Wang Y, Qiu L, Ranson H, Lumjuan N, Hemingway J, Setzer WN, Meehan EJ, Chen L: Structure of an insect epsilon class glutathione S-transferase from the malaria vector Anopheles gambiae provides an explanation for the high DDT-detoxifying activity. J Struct Biol 2008, 164:228-235.

62. Chiu TL, Wen Z, Rupasinghe SG, Schuler MA: Comparative molecular modeling of Anopheles gambiae CYP6Z1, a mosquito P450 capable of metabolizing DDT. Proc Natl Acad Sci USA 2008, 105:8855-8860.

63. Chung H, Bogwitz MR, McCart C, Andrianopoulos A, French-Constant RH, Batterham P, Daborn PJ: Cis-regulatory elements in the Accord retrotransposon result in tissue-specific expression of the Drosophila melanogaster insecticide resistance gene Cyp6g1. Genetics 2007, 175:1071-1077.

64. Santolamazza F, Calzetta M, Etang J, Barrese E, Dia I, Caccone A, Donnelly MJ, Petrarca V, Simard F, Pinto J, della Torre A: Distribution of knock-down resistance mutations in Anopheles gambiae molecular forms in west and west-central Africa. Malar J 2008, 7:74.

65. Lynd A, Weetman D, Barbosa F, Egyir Yawson A, Mitchell S, Pinto J, Hastings I, Donnelly MJ: Field, genetic, and modeling approaches show strong positive selection acting upon an insecticide resistance mutation in Anopheles gambiae s.s. Mol Biol Evo 2010, 27:1117-1125.

66. Pinto J, Lynd A, Vincente JL, Santolamazza F, Randle NP, Gentile G, Moreno M, Simard F, Charlwood JD, do Rosario VE, Caccone A, Della Torre A, Donnelly MJ: Multiple origins of knockdown resistance mutations in the Afrotropical mosquito vector Anopheles gambiae. PLOS ONE 2007, 2:e1243.

67. Weill M, Chandre F, Brengues C, Manguin S, Akogbeto M, Pasteur N, Guillet P, Raymond M: The kdr mutation occurs in the Mopti form of Anopheles gambiae s.s. through introgression. Insect Mol Biol 2000, 9:451-455.

68. Alout H, Berthomieu A, Cui F, Tan Y, Berticat C, Qiao C, Weill M: Different amino-acid substitutions confer insecticide resistance through acetylcholinesterase 1 insensitivity in Culex vishnui and Culex tritaeniorhynchus (Diptera: Culicidae) from China. J Med Entomol 2007, 44:463-469.

69. Djogbenou L, Dabire R, Diabate A, Kengne P, Akogbeto M, Hougard JM, Chandre F: Identification and geographic distribution of the ACE-1(R) mutation in the malaria vector Anopheles gambiae in south-western Burkina Faso, West Africa. Am J Trop Med Hyg 2008, 78:298-302.

70. Djogbenou L, Noel V, Agnew P: Costs of insensitive acetylcholinesterase insecticide resistance for the malaria vector Anopheles gambiae homozygous for the G119 S mutation. Malar J 2010, 9:12.

71. Djogbenou L, Chandre F, Berthomieu A, Dabire R, Koffi A, Alout H, Weill M: Evidence of introgression of the ace-1(R) mutation and of the ace-1 duplication in West African Anopheles gambiae s. s. PLoS One 2008, 3: e2172.

72. Hemingway J, Karunaratne SHPP: Mosquito carboxylesterases: a review of the molecular biology and biochemistry of a major insecticide resistance mechanism. Med Vet Entomol 1998, 12:1-12.

73. Wirth MC, Marquine M, Georghiou GP, Pasteur N: Esterases A2 and B2 in Culex quinquefasciatus (Diptera: Culicidae): role in organophosphate resistance and linkage. J Med Entomol 1990, 27:202-206.

74. Li CX, Dong YD, Song FL, Zhang XL, Gu WD, Zhao TY: Company amplification of estalpha2/estbeta2 and correlation between esterase gene copy number and resistance to insecticides in the field Culex pipiens pallens strains collected from Beijing, China. J Med Entomol 2009, 46:539-545.

75. Elliott R: Insecticide resistance in Anopheles gambiae Giles. Nature 1956, 177:532-533

76. Davidson G: Insecticide resistance in Anopheles gambiae Giles. A case of simple Mendelian inheritance. Nature 1956, 178:4535.

77. Davidson G, Hamon J: A case of dominant dieldrin resistance in Anopheles gambiae. Nature 1962, 196:1012.

78. Haridi AM: Linkage studies on DDT and dieldrin resistance in species A and species B of the Anopheles gambiae complex. Bulletin of the World Health Organisation 1974, 50:441-448.

79. Brooke BD, Hunt RH, Matambo TS, Koekemoer LL, van Wyk P, Coetzee M: Dieldrin resistance in the malaria vector Anopheles gambiae in Obuasi, Ghana. Med Vet Entomol 2006, 20:294-299.

80. Ffrench-Constant RH, Anthony N, Aronstein K, Rocheleau T, Stilwell G: Cyclodiene insecticide resistance: from molecular to population genetics. Annu Rev Entomol 2000, 45:449-466.
81. Brooke $\mathrm{BD}$, Hunt $\mathrm{RH}$, Coetzee $\mathrm{M}$ : A dieldrin resistance mechanism in the malaria vector Anopheles gambiae Giles assorts with inversion 2La. Med Vet Entomol 2000, 14:190-194.

82. Georghiou GP, Taylor CE: Genetic and biological influences in the evolution of insecticide resistance. J Econ Entomol 1977, 70:319-323.

83. Rinkevich FD, Hamm RL, Geden CJ, Scott JG: Dynamics of insecticide resistance alleles in house fly populations from New York and Florida. Insect Biochem Mol Biol 2007, 37:550-558.

84. Guillemaud T, Guillemaud T, Brun A, Anthony N, Sauge MH, Boll R, Delorme R, Fournier D, Lapchin I, Vanlerberghe-Masuffi F: Incidence of insecticide resistance alleles in sexually-reproducing populations of the peach-potato aphid Myzus persicae (Hemiptera: Aphididae) from southern France. Bull Entomol Res 2003, 93:289-297.

85. Anstead JA, Mallet J, Denholm I: Temporal and spatial incidence of alleles conferring knockdown resistance to pyrethroids in the peach-potato aphid, Myzus persicae (Hemiptera: Aphididae), and their association with other insecticide resistance mechanisms. Bull Entomol Res 2007, 97:243-253.

86. Alout H, Djogbenou L, Berticat C, Chandre F, Weill M: Comparison of Anopheles gambiae and Culex pipiens acetycholinesterase 1 biochemical properties. Comp biochem Physiol. Part B, Biochemistry and Molecular Biology 2008, 150:271-277

87. Rowland MW: Behaviour and fitness of $\gamma \mathrm{HCH} /$ dieldrin resistant and susceptible female Anopheles gambiae and An. stephensi mosquitoes in the absence of insecticide. Med Vet Entomol 1991, 5:193-206.

88. Rowland MW: Activity and mating competitiveness of $\gamma \mathrm{HCH} /$ dieldrin resistant and susceptible male and virgin female Anopheles gambiae and An. stephensi mosquitoes, with assessment of an insecticide rotation strategy. Med Vet Entomol 1991, 5:207-222.

89. Hemingway J, Small GJ, Monro A, Sawyer BV, Kasap H: Insecticide resistance gene frequencies in Anopheles sacharovi populations of the Cukurova plain, Adana Province, Turkey. Med Vet Entomol 1992, 6:342-348.

90. Brooke BD, Hunt RH, Chandre FC, Carnevale P, Coetzee M: Stable chromosomal inversion polymorphisms and insecticide resistance in the malaria vector mosquito Anopheles gambiae (Diptera: Culicidae). J Med Entomol 2002, 39:568-573.

91. Okoye PN, Brooke BD, Hunt RH, Coetzee M: Relative developmental and reproductive fitness associated with pyrethroid resistance in the major southern African malaria vector Anopheles funestus. Bull Entomol Res 2007, 97:599-605.

92. Hardstone MC, Lazarro BP, Scott JG: The effect of three environmental conditions on the fitness of cytochrome P450 monooxygenasemediated permethrin resistance in Culex pipiens quinquefasciatus. BMC Evol Biol 2009, 9:42.

93. Hunt RH: Location of genes on chromosome arms in the Anopheles gambiae group of species and their correlation to linkage data for other anopheline mosquitoes. Med Vet Entomol 1987, 1:81-88.

94. Zheng L, Benedict MQ, Cornel AJ, Collins FH, Kafatos FC: An integrated genetic map of the African human malaria vector mosquito, Anopheles gambiae. Genetics 1996, 143:941-952.

95. Haldane JBS: The conditions for coadaptation in polymorphism for inversions. J Genet 1957, 55:218-225.

96. Manoukis NC, Powell JR, Toure MB, Sacko A, Edillo FE, Coulibaly MB, Traore SF, Taylor CE, Besansky NJ: A test of the chromosomal theory of ecotypic speciation in Anopheles gambiae. Proc Natl Acad Sci USA 2008, 105:2940-2945

97. Coluzzi M, Sabatini A, Petrarca V, Di Deco MA: Chromosomal differentiation and adaptation to human environments in the Anopheles gambiae complex. Trans R Soc Trop Med Hyg 1979, 73:483-497.

98. Bayoh MN, Thomas CJ, Lindsay SW: Mapping distributions of chromosomal forms of Anopheles gambiae in West Africa using climate data. Med Vet Entomol 2001, 15:267-274.

99. Gray EM, Rocca KAC, Costantini C, Besansky NJ: Inversion 2La is associated with enhanced desiccation resistance in Anopheles gambiae. Malar J 2009, 8:215.

100. Petrarca V, Beier JC: Intraspecific chromosomal polymorphism in the Anopheles gambiae complex as a factor affecting malaria transmission in the Kisumu area of Kenya. Am J Trop Med Hyg 1992, 46:229-237.

101. Dabire KR, Diabate A, Djogbenou L, Ouari A, N'Guessan R, Ouedraogo JB, Hougard JM, Chandre F, Baldet T: Dynamics of multiple insecticide 
resistance in the malaria vector Anopheles gambiae in a rice growing area in South-Western Burkina Faso. Malar J 2008, 7:188.

102. Kulathinal RJ, Bettencourt BR, Hartl DL: Compensated deleterious mutations in insect genomes. Science 2004, 306:1553-1554.

103. Chanda E, Masaninga F, Coleman M, Sikaala C, Katebe C, Macdonald M, Baboo KS, Govere J, Manga L: Integrated vector management: the Zambian experience. Malar J 2008, 7:164.

doi:10.1186/1756-3305-3-74

Cite this article as: Brooke and Koekemoer: Major effect genes or loose confederations? The development of insecticide resistance in the malaria vector Anopheles gambiae. Parasites \& Vectors 2010 3:74.

Submit your next manuscript to BioMed Central and take full advantage of:

- Convenient online submission

- Thorough peer review

- No space constraints or color figure charges

- Immediate publication on acceptance

- Inclusion in PubMed, CAS, Scopus and Google Scholar

- Research which is freely available for redistribution

Submit your manuscript at www.biomedcentral.com/submit
C Biomed Central 